\title{
The Prospect of Bentazone-Tolerant Soybean for Conventional Cultivation
}

\author{
Liakat Ali ${ }^{1,2}$, Hyun Jo ${ }^{1}$, Jong Tae Song ${ }^{1(\mathbb{D})}$ and Jeong-Dong Lee ${ }^{1, *(1)}$ \\ 1 School of Applied Biosciences, College of Agriculture and Life Sciences, Kyungpook National University, \\ Daegu 41566, Korea; liakat.gpb@bsmrau.edu.bd (L.A.); johyun@knu.ac.kr (H.J.); jtsong68@knu.ac.kr (J.T.S.) \\ 2 Department of Genetics and Plant Breeding, Faculty of Agriculture, Bangabandhu Sheikh Mujibur Rahman \\ Agricultural University, Gazipur 1706, Bangladesh \\ * Correspondence: jdlee@knu.ac.kr
}

Received: 7 September 2020; Accepted: 22 October 2020; Published: 26 October 2020

check for updates

\begin{abstract}
Soybean is one of the most important crops widely used as food, feed, and industrial products. Weeds compete with the crops for light, nutrients, water, space, and other growth requirements, causing an average yield reduction of $37 \%$ in soybean. Bentazone is an herbicide that selectively kills broadleaf weeds by inhibiting photosynthesis. It is widespread in soybean-cultivating areas including genetically modified organism (GMO) and GMO-free regions all around the world. This herbicide carries a double-edged sword since it can also incur damage to crops upon application. The challenge, therefore, lies in the deliberate selection of bentazone-tolerant cultivars. We systematically analyzed several factors that affect the metabolism of bentazone in soybean, such as phenotypic and genotypic differences among soybean accessions, the time and method of application, the absorption and metabolism of bentazone in soybean, and the effects of effective application and cultivar selection on yield and crop injury. Furthermore, we recommend that further studies should be done in aid of discovering more tolerant soybean cultivars. We hope that our review will help farmers and soybean producers, as well as geneticists, in developing bentazone-tolerant soybean cultivars to improve the global yield of soybean crops as a response to the ever-dynamic food demand across the globe.
\end{abstract}

Keywords: soybean; bentazone; photosystem-II inhibitor; cytochrome P450; enzymatic detoxification

\section{Introduction}

Weeds reduce farm and forest productivity, invade crops, smother pastures, and harm livestock in several cases [1]. Weeds compete with crops for light, nutrients, water, space, and other growth requirements, thereby reducing the crop quality and yield. They also produce harmful chemicals that affect the growth of associated crops (allelopathic effect) and serve as an alternative host to pests and diseases of crops [2]. In soybeans (Glycine max (L.) Merr.), weeds alone can cause an estimated average reduction of $37 \%$ in yield, whereas other fungal diseases and agricultural pests account for $22 \%$ of losses [3]. On average, soybean yield in organic systems was 19\% lower than that in conventional systems, and weed competition alone accounted for this difference [4]. Yield loss for soybean grown with pigweed (Amaranthus palmeri), crabgrass (Digitaria sanguinalis), and common ragweed (Ambrosia artemisiifolia) ranged from $14 \%$ to $37 \%, 0 \%$ to $37 \%$, and $40 \%$ to $95 \%$, respectively [5]. Weed management is essential for any current agricultural production system, especially for large monoculture areas that are affected by a great extent of environmental pressure. Soybean is one of the largest monocultures in the world, with 122.44 million ha harvested in 2019 [6].

Management of unwanted weeds and other plants should be cost-effective for agricultural and other related industries. Herbicides can provide cheap weed control and reduce workload, because 
they can be used during and after emergence for weed control in crop production, forestry, industry, and non-cultivated areas. Although chemical weed control began over a century ago with inorganic compounds, the ever-increasing regulatory and economic pressures have transitioned to the age of organic herbicides [7]. Herbicides are favorably comparable with other methods in terms of net energy profit due to weed control, because yield was nearly as high as that achieved with hand labor [8]. Among many other factors, herbicide use was one of the major factors for an increase in the yield of all types of crops between 1940 and 2010 [7]. Thus, the global weed control market has been accounted for USD 28.08 billion in 2017 and is expected to reach USD 44.90 billion by 2026 growing at a compound annual growth rate of $5.35 \%$ during the forecast period [9]. Farmers routinely apply herbicides to more than $85 \%$ of the crop area in the USA [10]. Herbicides, as primary tools for weed control in the United States, were shown by the fact that the number of herbicides included in the Herbicide Handbook of the Weed Science Society of America (WSSA) had grown from 97 representing 27 site-of-action groups in the first edition in 1967 to 232 from 67 chemical structural groups divided into 24 site-of-action groups in the tenth edition in 2014 [11,12]. Milne [13] listed 442 herbicides approved for use worldwide.

Based upon the time of application, herbicides are classified as pre-emergence (PRE) or post-emergence (POST) [14]. Herbicides are classified according to the site of uptake (foliar and soil herbicides), mode of action (contact and systemic), and herbicidal activity (residual and non-residual herbicides) $[15,16]$. Selectivity is the potential of an herbicide to kill certain plants without injuring others. When applied POST herbicide, they may be selective (specific target) or nonselective (kill all plants when applied at the right rate) [17]. Herbicide selectivity is subjective, depending on several variables, including plant biology, climate, rate of application of herbicides, timing of application, sequestration of herbicides or over-expression of the target protein, and application techniques [18,19].

In this review, we summarized information of bentazone application, such as environmental factors influencing application, absorption, metabolism of bentazone, and inheritance of bentazone tolerance genes in plants. In addition, we focused on the review of bentazone application in soybean, and phenotypic and genotypic variation in soybean accessions. We hope that our review will help farmers and soybean producers to improve herbicide efficiency in soybean production across the world, as well as geneticists for developing bentazone-tolerant soybean cultivars.

\section{Bentazone}

Herbicides are selected based on several factors for successful weed control, including weed range, lack of crop injury, effect of agro-ecosystem, economic cost, and policy. Bentazone [3-Isopropyl1H-2,1,3-benzothiadiazin-4(3H)-one 2,2-dioxide] was initially registered in 1975. It has been used for selective POST control of broadleaf weeds and sedges in alfalfa, asparagus, cereals, clover, digitalis, dry peas, flax, garlic, grass, green lime beans, mint, onions, potatoes, snap beans for seeds, sorghum, soybeans, and sugarcane [20-23]. Bentazone is a contact herbicide that interferes with susceptible plants' ability to use sunlight in producing survival energy through photosynthesis. Visible damages on the surface of leaves were usually observed after a few hours to weeks of treatment with bentazone, depending on the species and dosage [24-26]. Bentazone is absorbed by leaves upon application as a foliar spray, accompanied by rapid break-down or metabolism into natural plant components and metabolites in resistant plants, such as starch, protein, lignin, amino acid, and cellulose [26]. When bentazone is absorbed by the roots, it is translocated from the roots to other parts of the plants through xylem, with plant nutrients in the transpiration stream [27]. However, the degree of translocation is dependent on plant species after absorption by leaves. In susceptible and resistant soybean genotype, the amount of absorbed bentazone translocated from the treated leaf was 7 to 13 percent of the total absorption [28]. In addition, foliar application of bentazone to soybean resulted in slow acropetally translocation of the herbicide [29]. In tolerant rice, most of the ${ }^{14} \mathrm{C}$-bentazone remained in the treated leaf or translocated to older leaves, whereas most of the ${ }^{14} \mathrm{C}$-bentazon was translocated from the treated leaves to younger leaves in susceptible rice [26]. Acropetal and basipetal translocation of absorbed ${ }^{14} \mathrm{C}$ from ${ }^{14} \mathrm{C}$-bentazon was equal in corn [30]. Most of the absorbed ${ }^{14} \mathrm{C}$-bentazone in capsicum species 
remained in the treated leaves, with minimal acropetal and basipetal translocation from the site of application [31]. For some susceptible weed species (yellow nutsedge, Canada thistle) the translocation was acropetal transport [29,32].

The adverse effect of bentazone on agro-biodiversity as well as soil fertility is less than that of other selective contact herbicides [33]. Bentazone concentration at the field does not considerably affect the microflora even without microbial degradation [34,35]. In case of 2,4-D, it adversely affects the activities of Rhizobium sp. and glyphosate suppresses the phosphatase activity of purple non-sulfur bacteria in soil, decreasing the growth and activity of azotobacter as well as $\mathrm{N}$-fixation in soybean [36]. Compared with other POST broadleaf herbicides, bentazone is quickly degraded in the soil [37,38]. For soil fertility, bensulfuron methyl and metsulfuron-methyl reduces the operation of $\mathrm{N}$-mineralization. In addition, prometryn, simazine, and terbutryn inhibit not only the $\mathrm{N}$-fixation, but also reduce the total number of nodules and $\mathrm{N}$ in soil. Furthermore, glyphosate, sulfonylurea and atrazine also dramatically alter soil structure with the disturbances in soil earthworm ecology and the inhibition of soil N-cycle under alkaline or low organic matter [39].

Since bentazone was originally evaluated by the Joint FAO/WHO meeting on Pesticide Residues (JMPR) in 1991, the re-evaluation was periodically conducted until now. The evaluation reported residue of parent bentazone and its metabolites such as 6- and 8-hydroxy-bentazone atter its application in seed, food, and feed of plant. In USA, the limit of detection by gas liquid chromatography method for compounds of bentazone and its metabolites in soybean was $0.05 \mathrm{ppm}$ according to a rule by the environmental protection agency in 2019 [40]. In Europe, the maximum residue level for soybean was 0.01 ppm based on a report of pesticide residues in food in 2013 [41]. In addition, based on carcinogen assessment by environmental protection agency, bentazone was found not to be mutagenic and was classified as a Group E chemical, which means evidence of non-carcinogenicity for humans [42].

\subsection{Bentazone Effectivity Modulated by Environmental Conditions}

The effective utilization of herbicides is determined by environmental conditions before, during, and after its application [43]. Increasing light intensity at the application of herbicide results in higher photosynthesis and subsequent phloem translocation to increase the movement of foliar-applied herbicides. The stomata remain open at high light intensity, thus increasing tissue penetration of foliar herbicides [43]. Thus, the effectiveness of POST herbicides depends on light intensity during application.

One of the most important environmental factors are air temperature and relative humidity (RH), which alter the performance of herbicides in weed control. Absorption and translocation of bentazone in plant increases with higher temperatures [44]. At high temperatures, herbicide absorption is enhanced through reduced cuticle waxes and increased herbicide diffusion through the cuticle [43]. With high temperatures and high RH levels, the cuticle is highly hydrated, thereby promoting absorption of herbicides [45].

Generally, humidity has a greater effect on herbicide uptake than temperature [46]. Increased humidity increases the uptake of bentazone. For instance, increased uptake of bentazone at $80 \% \mathrm{RH}$ rather than one at $40 \% \mathrm{RH}$ was observed in seven plant species [44]. Additionally, high RH levels favor the efficiency of foliar-applied herbicides by affecting herbicide uptake through interactions between the herbicide droplet, leaf cuticle, stomatal opening, and water in or around droplets [47]. The effects of low humidity on bentazone uptake can be overcome by adding adjuvants. For example, enhancement of bentazone uptake by adjuvants was more pronounced at $40 \% \mathrm{RH}$ than at $80 \% \mathrm{RH}$ [44]. Bentazone was found to be very mobile in soil at natural RH due to its high-water solubility [47]. Bentazone's herbicidal activity is very low in dry soil; however, its activity increases with increasing soil moisture content and highly active at slightly flooded conditions [47]. Herbicide performance is generally reduced on moisture stressed plants under dry or low soil moisture conditions because plant morphology and physiology are both affected [48]. Understanding of the environmental factors that cause low herbicide efficiency makes it possible to consider the appropriate conditions such as temperature and humidity to spray, thereby maximizing the dose applied and minimizing the processing costs. 


\subsection{Tolerance Mechanism for Bentazone}

The WSSA defines herbicide resistance as "the inherited ability of a plant to survive and reproduce following exposure to a dose of herbicide normally lethal to the wild type, and may be naturally occurring or induced by techniques, such as genetic engineering or selection of variants produced by tissue culture or mutagenesis" [49]. Herbicide resistance mechanisms include structural reforms at the target site of the herbicide, metabolic detoxification, and changes in herbicide uptake, translocation, or compartmentalization [50]. Plant species that are not controlled by a herbicide before any selection pressure or genetic manipulation can be considered naturally tolerant, but not herbicide-resistant [51].

Bentazone tolerance requires mechanisms that limit the amount of active herbicide entering the target site, mechanisms that decrease herbicide uptake, and mechanisms that improve herbicide metabolism. Differential absorption and metabolism in treated bentazone-susceptible line leaflets resulted in a higher bentazone concentration than that of tolerant species, revealing that differential metabolism is the key cause of different responses to bentazone [30,52]. Tolerant plants can easily detoxify bentazone through rapid aryl hydroxylation followed by glucose conjugation, whereas susceptible plants metabolize bentazone to a lesser extent, and several species are unable to metabolize it at all. The absorbed bentazone was hydroxylated to either 6-hydroxy-bentazone or 8-hydroxy-bentazone and then glycosylated at positions 6 or 8 of its aromatic ring, which was eventually oxidized to produce natural plant products, such as starch, protein, lignin, amino acid, and cellulose [53]. Base on the species, the positions of its aromatic ring of hydroxylation and glycosylation are different. Bentazone is readily metabolized in rice and other gramineous plants by detoxifying this herbicide primarily by 6-hydroxylation or 6- and 8-hydroxylation and glucose conjugation of its hydroxylated positions [54]. Sorghum and Johnsongrass [55] rapidly metabolizes bentazone by producing 6-hydroxylbentazone, whereas wheat [54], corn [56], and soybean [28] metabolizes it by producing 6- and 8-hydroxyl-bentazone after hydroxylation followed by glycosylation at the 6 and 8 positions of its aromatic ring.

Metabolic resistance of bentazone are generated by endogenous cytochrome P450 mono-oxygenases, glucosyl transferases (GTs), glutathione S-transferases (GSTs), and/or other enzyme systems, such as aryl acylamide [57]. Hydroxylation of aromatic rings or alkyl groups by a family of enzymes known as cytochrome P450 mono-oxygenases and then, glucose conjugation at positions of its aromatic ring by GSTs or GTs is the most common way to detoxify herbicides in plants $[58,59]$.

\subsection{Inheritance and Genes Controlling Bentazone Tolerance in Crops}

Several studies have reported different responses to bentazone in crops, such as rice [60], maize [61], potato [62], sweet potato and pumpkin [63], cowpea [64], red bean [65], lentil and pepper [66], peanut [67], clover [68], and blueberry [69].

In previous studies, the cytochrome P450 family has been identified to detoxify bentazone in various plants [23,56,70]. In rice, a Bel-encoded cytochrome P450 mono-oxygenase, CYP81A6, mediated resistance to bentazone. The loss of bentazone resistance in rice resulted from a single base-pair deletion of CYP81A6 [23,71]. Additionally, Fang et al. [72] reported that a 519-kD transcription factor-like protein (B9FDA1) containing two histidine kinase-like ATPase domains and a zinc-finger type C3HC4 RING domain can serve as a transcription factor for the expression of bentazone tolerance genes in rice.

In soybean, the gene expression pattern of certain cytochrome P450 homologs, such as CYP94A1, CYP82A2, CYP71D8, and CYP81E8, occurred when plants were treated with bentazone [28]. Bernard and Wax [73] reported that the inheritance of bentazone sensitivity in soybean was controlled by a single recessive gene. A single recessive gene ( $b n z-1)$ was mapped to chromosome 16 for bentazone sensitivity of soybean, where a single base-pair deletion in the coding region of GYP81E22 (Glyma.16G149300) at $+1465 \mathrm{bp}$ downstream from the translation start codon led to a premature stop codon and loss of function of cytochrome P450 hydroxylase [74]. Several compounds inhibit both soybean aryl hydroxylation and cytochrome $\mathrm{P} 450$ reactions, provided by in vivo evidence of bentazone metabolism facilitated by cytochrome P450 [70]. For GTs, Leah et al. [70] isolated and purified two enzymes from bentazone-tolerant soybean to produce the glycosylated 6- or 8-hydroxybentazone. 
POST application of bentazone reported initially the susceptibility of various in-breeds in the study of inheritance of single crosses of corn, which may be attributed to a single recessive gene, named ben [61]. Several studies supported that the ben locus may be responsible for bentazone sensitivity by cytochrome P450 monooxygenase in white-kernel inbred [75] and sweet corn [76]. In addition, another study of an in vitro assay with corn reported that bentazone aryl hydroxylation of maize microsomes is catalyzed by cytochrome P450 mono-oxygenase [56].

Bentazone tolerance of Capsicum annuum was also controlled by a single dominant gene [77]. A dominant Bzt gene responsible for bentazone tolerance in pepper cultivar "Santaka" may be the same gene or may be closely linked to the Bzt locus that confirms bentazone tolerance in "Bohemian Chili" [66].

New technologies involved in genetically modifying herbicide-resistant cultivars help in managing alternatives to glyphosate. Several of them that are still being tested may be available for release on short notice [78]. Bentazone-resistant species of cotton [79,80], tobacco, and Arabidopsis [81] were developed through genetic transformation of the bentazon-resistant gene (Cyp81A6) from rice. Additionally, rat CYP1A1 was transformed for potato bentazone-resistant cultivars [82].

\subsection{Pre- and Post-Emergence Herbicides for Soybean Production}

Soybean is one of the most important crops and is widely used as a staple for human food, animal feed, and industrial products globally. Soybeans are high in protein $(40 \%)$, and they are a major ingredient in livestock feed. Soybeans are processed for their oil and meal, and a smaller percentage is processed for human consumption and made into soy milk, soy flour, soy protein, tofu, and many other retail food products [83].

Despite having advanced technologies, weeds are considered the number one problem in major soybean-producing countries. Weed management strategies depend on significant biological factors, such as weed and crop intensity, seedbank processes, demographic variability, and weed-crop rivalry and reproductive biology [84]. Before starting weed management in soybean fields, we should think about resources, and how and when to use them. Apparently, due to countless cases of resistance, weed control strategies that integrate traditional, physical, and chemical controls are preferred [85]. Herbicides are important tools in weed control in the wide spectrum of practice, particularly for those with a large number of chemical-resistant crops.

During initial establishment, PRE herbicides can help farmers maintain weed-free fields and also reduce pressure on POST herbicides. PRE herbicides can be applied before or up to $3 \mathrm{~d}$ after planting. Tillage and PRE herbicides were the most popular weed control systems in soybeans in the 1970s [85]. Dinitroanilines, fluchloralin, and vernolate were used in pre-planting and incorporated for annual grass and broadleaf weed control [85]; triazines were also used in PRE applications for small seeded broadleaves, often in combination with alachlor to improve annual grass control [86]; and linuron, offering broad spectrum control, was also used in PRE application [87]. There have been many weed issues, such as perennial grasses and the usual widespread weeds of summer crops, due to the limited choices in soybean herbicides. The creation of several new chemicals during the $80 \mathrm{~s}$ and 90s improved weed control, although their application is still combined with mechanical tools, before glyphosate-resistant soybeans were introduced [85]. Acifluorfen, a chemical that controls large-seeded broadleaf weeds, has become a common treatment rescue method, although it has caused serious crop injury [88]. It was partly replaced by another diphenylether, fomesafen; however, it still lacked the same efficacy or control spectrum [89]. The registration of acetolactate synthase-inhibiting herbicides (sulfonylureas, imidazolinones, and triazolopyrimidines) has sparked a new era of soybean weed control, allowing for PRE/POST combinations and providing effective and persistent control of the most important weeds, with less crop injury than previous chemicals [90]. Several recently developed PRE herbicides with advanced options, such as flexibility across tillage systems, multiple modes of action, longer residual effects, and higher yield potential, are BroadAXE, prefix, boundary [91]. 
Glyphosate is a non-selective herbicide, and it can be applied from emergence to full flower season in glyphosate-resistant soybean field.

The introduction of POST bentazone revolutionized the market, enabling the control of large dicotyledonous weeds [85]. However, POST application was only limited to the same herbicides (bentazone, imazethapyr, setoxydine, tepraloxydyme, ethyl-chlorimurone, diclosulam, chlorasulan-methyl, etc.). In the late 1990s, new protoporphyrinogen oxidase enzyme inhibitors were developed [92]. Carfentrazone, sulfentrazone (aryl triazinones), and flumioxazine (an N-phenylphtalimide derivative) offered new options for burndown (carfentrazone) and residual control (sulfentrazone and flumioxazine); however, the introduction of the glyphosate-resistant soybean varieties prevented their utilization, with the launch of glyphosate-resistant varieties in 1996 being the most drastic expansion of soybean output [85].

Soybeans are most sensitive to weed competition at $4-7$ weeks after emergence [93]. The window to control broadleaf weeds is very small, and the best results are obtained on weeds with less than four leaves. POST broadleaf weeds may be controlled with Spinnaker ${ }^{\circledR}$ (Imazethapyr), Broadstrike ${ }^{\circledR}$ (flumetsulam), Basagran ${ }^{\circledR}$ (bentazone), Blazer ${ }^{\circledR}$ (Acifluorfen), and Raptor ${ }^{\circledR}$ (imazamox). Mixtures of Basagran ${ }^{\circledR}$ and Blazer ${ }^{\circledR}$ have been commonly used to increase the activity spectrum. The most current herbicides used for weeding management in corn, soybean, and cotton are selective and typically used in mixtures to control a broad spectrum of weed species [90].

Although glyphosate provided the most effective weed control when applied with other broadleaf herbicides [94], researchers at the University of Wisconsin compiled results from a variety of trials conducted in eight northern states, finding that Roundup Ready soybean varieties yields were $4 \%$ lower than conventional soybean varieties yields, on average, in 1998 [95]. Thus, farmers need to act now to diversify their herbicides, methods, crops, and their traditional practices.

\subsection{Utilization of Bentazone in Soybean Production}

Bentazone is a POST broadleaf herbicide that is widely used in soybeans. Annual broadleaf weed species can reduce soybean yield by more than 50\%. Ambrosia spp. and Amaranthus spp. are frequently reported in literature and regarded as the most noxious broadleaf weeds in soybean. Bentazone prevents weed growth in grain-type soybean as well as vegetable soybean fields [96]. Soybean yield and harvestable soybean losses were prevented by pre-harvest application of a mixture of bentazone and acifluorfen, as well as bentazone and imazamox. The total weed control output of bentazone in conjunction with imazamox and typhenesulfuron was 95.04\% [97]. Application of glyphosate tank mixtures with bentazone was more selective to Roundup Ready soybean when applied at younger stages [98].

Bentazone responses in soybean plants were classified into three types, namely tolerant, moderately sensitive, and highly sensitive [99]. While bentazone application causes minor injuries in tolerant soybean cultivars, plants gradually recover with growth, resulting in a marginal reduction in yield [100]. Compared to other broadleaf herbicides, application of bentazone produces less leaf injury and yield reduction in soybean (Table 1) [25,101-109]. 
Table 1. List of PRE and POST herbicides that commonly used to control broadleaf weed management in soybean.

\begin{tabular}{|c|c|c|c|c|c|c|}
\hline Active Ingredient & Chemical Family & Time of Application & Mode of Application & $\begin{array}{l}\text { Soybean Stages } \\
\text { at Application }\end{array}$ & Mode of Action & Injury Leaf or Yield \\
\hline Bentazone & Benzothiadiazole & POST & Foliar & $2-3$ trifoliate stage & Photsystem-II interference & $\begin{array}{l}\text { Leaf injury depends } \\
\text { on genotypes }\end{array}$ \\
\hline Chlorimuron-ethyl & Sulfonylurea & POST & Foliar & 2 trifoliate stage & Inhibition of acetolactate synthase (ALS) & $5 \%$ or less of leaf injury \\
\hline Thifensulfuron & Sulfonylurea & POST & Foliar & 2 trifoliate stage & Inhibition of acetolactate synthase (ALS) & $22 \%$ of leaf injury \\
\hline Chlorimuron & Sulfonylurea & POST & Foliar & $1-2$ trifoliate stage & Inhibition of acetolactate synthase (ALS) & $22 \%$ of leaf injury \\
\hline Chlorosulfuron & Sulfonylurea & POST & Foliar & $1-2$ trifoliate stage & Inhibition of acetolactate synthase (ALS) & $27 \%$ reduced yield \\
\hline Imazamox. & Imidazolinone & POST & Foliar & $1-2$ trifoliate stage & Inhibition of acetolactate synthase (ALS) & $23 \%$ of leaf injury \\
\hline Imazethapy & Imidazolinone & POST & Foliar, Soil & 2 trifoliate & Inhibition of acetolactate synthase (ALS) & $35 \%$ of leaf injury \\
\hline Imazaquin & Imidazolinone & POST & Foliar & 1-2 trifoliate stage & Inhibition of acetolactate synthase (ALS) & $13 \%$ of leaf injury \\
\hline Mesotrione & Triketone & POST & Foliar & 1 trifoliate stage & $\begin{array}{l}\text { 4-Hydroxyphenylpyruvate } \\
\text { dioxygenase Inhibitors }\end{array}$ & $25-78 \%$ of leaf injury \\
\hline Fomesafen & Diphenylether & POST & Foliar & $1-2$ trifoliate stage & $\begin{array}{l}\text { Cell Membrane Disrupters } \\
\text { (PPO Inhibitors) }\end{array}$ & $25 \%$ of leaf injury \\
\hline Lactofen & Diphenylether & POST & Foliar & Before full seed stage & $\begin{array}{l}\text { Cell Membrane Disrupters } \\
\text { (PPO Inhibitors) }\end{array}$ & 29 and $34 \%$ of leaf injury \\
\hline Acifluorfen & Diphenylether & PRE, POST & Foliar, Soil & 3 trifoliate stage & $\begin{array}{l}\text { Cell Membrane Disrupters } \\
\text { (PPO Inhibitors) }\end{array}$ & $20 \%$ of leaf injury \\
\hline Propanil & Phenyl-pyridazine & POST & Foliar & $1-2$ trifoliate stage & Pigment Inhibitors & $10-30 \%$ of leaf injury \\
\hline Quinclorac & Quinolines & POST & Foliar & 1 trifoliate stage & Not completely understood & $46 \%$ of leaf injury \\
\hline Bromoxynil & Nitrile & PRE, POST & Foliar & 1 trifoliate stage & Photosystem II inhibitor & \\
\hline
\end{tabular}




\subsection{Genetic Resources and Genetic Information for Bentazone Tolerance in Soybean}

There are a number of reports of differential responses to herbicides by crop cultivars. Differential cultivar response is displayed in a number of ways, including different injury symptoms, growth retardation, and possible effects on yield [110]. Identifying and characterizing these differences may be helpful in preventing substantial crop injury and developing more tolerant lines for the future. A total of 338 soybean germplasms in the collection of the US Department of Agriculture were evaluated under field conditions. "Beeson", "Amsoy", "Amsoy 71", "Calland”, "Clark 63", and "Corsoy" were found to be bentazone-tolerant, whereas one US cultivar, "Hurrelbrink", and ten Japanese lines were highly sensitive to bentazone [111].

Other studies reported that different absorption and metabolism rates between bentazone-tolerant and bentazone-sensitive soybean resulted in a greater concentration of bentazone in the treated leaflet of susceptible cultivars than in that of tolerant cultivars after foliar treatment. Different bentazone metabolism rates appear to be the main cause of the different responses of these soybean cultivars to bentazone [52]. An experiment was performed to reconfirm the tolerant cultivars' differential metabolism of bentazone, which indicated that tolerant genotypes are 100-300 times more tolerant to bentazone than susceptible genotypes. Tolerant genotypes ("Hill" and "Clark 63") metabolized 80-90\% of ingested bentazone within 24 h, whereas sensitive genotypes ("L78-3263", "Hurrelbrink", and "PI229342") metabolized just 10-15\% [28]. A vegetable-type soybean, AVS-4002, which is resistant to bentazone as a POST application of tank mixture of bentazone and imazamox on vegetable soybean, was found to have no harmful effects, such as crop injury, and did not affect yield [112].

Recently, we screened 410 cultivated soybeans, 384 wild soybeans (Glycine soja Sieb. and Zucc.), and 1300 mutant lines derived from $0.3 \%$ ethyl methanesulfonate (EMS) to select either bentazone-tolerant or -sensitive lines. The reaction of soybean lines to bentazone was normally distributed and several tolerance sensitive lines were found. Among them ten sensitive lines were compared in terms of sequence variation for Glyma.16G149300, which controls bentazone sensitivity in soybean. Our results showed that there was no deletion at the physical position 30,994,760 among 10 soybean lines. However, we found a haplotype, including four single nucleotide polymorphisms (SNPs) in exon 1 and 2 of Glyma.16G149300 through a sequence analysis of the coding regions of 10 sensitive lines; C-T at the physical position 30,993,331, G-C at 30,993,682, A-G at 30,994,898, and A-C at 30,995,057 (Figure 1). Since four SNPs were silent mutations, further researches were required to show the expression level of Glyma.16G149300 with 10 sensitive lines. Through sequence analysis, we assume that there may be different gene(s) controlling bentazone sensitivity in these soybean lines. In addition, these selected soybean lines can be used as genetic resources for further genetic studies of bentazone treatment. 


\begin{tabular}{|c|c|c|c|c|c|c|c|c|c|c|c|c|c|c|c|c|c|c|}
\hline \multirow{2}{*}{ Name } & \multirow{2}{*}{ Species } & \multirow{2}{*}{$\begin{array}{c}\text { Response to } \\
\text { bentazone }\end{array}$} & \multicolumn{3}{|c|}{ SNP1 $(30,993,331)$} & \multicolumn{3}{|c|}{ SNP2 $(30,993,682)$} & \multicolumn{3}{|c|}{$\begin{array}{c}\text { Deletion } \\
(30,994,760)\end{array}$} & \multicolumn{3}{|c|}{ SNP3 $(30,994,898)$} & \multicolumn{3}{|c|}{ SNP4 $(30,995,057)$} & \multirow{2}{*}{ References } \\
\hline & & & Ref & Alt & Mutation & Ref & Alt & Mutation & Ref & Alt & Mutation & Ref & Alt & Mutation & Ref & Alt & Mutation & \\
\hline Suwon98 & Glycine $\max$ & Sensitive & C & $\mathrm{T}$ & & G & C & & C & $\mathrm{C}$ & & A & G & & A & C & & \\
\hline PI97150 & Glycine $\max$ & Sensitive & $\mathrm{C}$ & $\mathrm{T}$ & & G & $\mathrm{C}$ & & $\mathrm{C}$ & $\mathrm{C}$ & & A & G & & A & $\mathrm{C}$ & & \\
\hline YWS689 & Glycine soja & Sensitive & $\mathrm{C}$ & $\mathrm{T}$ & & G & $\mathrm{C}$ & & $\mathrm{C}$ & $\mathrm{C}$ & & $\Lambda$ & G & & $\Lambda$ & $\mathrm{C}$ & & \\
\hline Daepung & Glycine $\max$ & M. tolerant & $\mathrm{C}$ & $\mathrm{T}$ & & G & $\mathrm{C}$ & & C & C & & A & G & & A & $\mathrm{C}$ & & \\
\hline PE79 & Glycine max & Sensitive & $\mathrm{c}$ & $\mathrm{T}$ & $\begin{array}{c}\text { Silent } \\
\text { mutation }\end{array}$ & G & $\mathrm{C}$ & $\begin{array}{c}\text { Silent } \\
\text { mutation }\end{array}$ & $\mathrm{C}$ & $\mathrm{C}$ & & A & G & $\begin{array}{c}\text { Silent } \\
\text { mutation }\end{array}$ & A & $\mathrm{c}$ & $\begin{array}{c}\text { Silent } \\
\text { mutation }\end{array}$ & Present study \\
\hline PE361 & Glycine $\max$ & Sensitive & $\mathrm{C}$ & $\mathrm{T}$ & & G & $\mathrm{C}$ & & $\mathrm{C}$ & $\mathrm{C}$ & & A & G & & A & $\mathrm{C}$ & & \\
\hline PE1293 & Glycine $\max$ & Sensitive & C & $\mathrm{T}$ & & G & $\mathrm{C}$ & & $\mathrm{C}$ & $\mathrm{C}$ & & A & G & & A & $\mathrm{C}$ & & \\
\hline PE1571 & Glycine $\max$ & Sensitive & $\mathrm{C}$ & $\mathrm{T}$ & & G & $\mathrm{C}$ & & $\mathrm{C}$ & C & & A & G & & A & $\mathrm{C}$ & & \\
\hline PE2722 & Glycine max & Sensitive & $\mathrm{C}$ & $\mathrm{T}$ & & G & $\mathrm{C}$ & & $\mathrm{C}$ & $\mathrm{C}$ & & A & G & & A & $\mathrm{C}$ & & \\
\hline Hannam & Glycine $\max$ & Sensitive & $\mathrm{C}$ & $\mathrm{T}$ & & G & $\mathrm{C}$ & & $\mathrm{C}$ & $\mathrm{C}$ & & A & G & & A & $\mathrm{C}$ & & \\
\hline Pureun & Glycine $\max$ & M. sensitive & $\mathrm{C}$ & $\mathrm{C}$ & & G & G & & C & C & & A & A & & A & A & & Present study \\
\hline YWS566 & Glycine soja & Sensitive & $\mathrm{C}$ & $\mathrm{C}$ & & G & G & & $\mathrm{C}$ & $\mathrm{C}$ & & A & $\Lambda$ & & $\Lambda$ & A & & \\
\hline Himeshirazu & Glycine max & Sensitive & C & C & & G & G & & C & - & $\begin{array}{c}\text { Prematures stop } \\
\text { codon }\end{array}$ & & & & & & & [82] \\
\hline Fukuyutaka & Glycine max & Tolerant & $\mathrm{C}$ & $\mathrm{C}$ & & G & G & & $\mathrm{C}$ & $\mathrm{C}$ & & A & A & & A & A & & [82] \\
\hline
\end{tabular}

Figure 1. Four single nucleotide polymorphisms (SNPs) in exon 1 and 2 for soybean genotypes with bentazone susceptible. (a) gene model of Glyma.16G149300 where black boxes indicate exon regions, white box indicates untranslated region and black lines indicates intron region. Single nucleotide polymorphism in the exon region is marked with a red asterisk. (b) Bentazone response for selected soybean lines, and their SNP information for SNP positions. Daepung, Hannam, and Puren are Korean soybean cultivars [113], PEs were from ethyl methanesulfonate (EMS) mutagenesis of "Pungsannamul", "Suwon98" and "PI97150" are germplasms. YWS689 and YWS566 are wild soybean germplasms. Kato et al. [76] identified that a single-base deletion was observed in the coding region of Glyma.16G149300 at physical position 30,994,760, resulting premature stop codon. Digits in parenthesis indicates physical position of SNP in soybean genome. Ref; reference SNP on W82.a2.V1, Alt; Alternative. 


\section{Future Perspective and Conclusion}

Since genetically modified (GM) soybean was developed, growers have switched to adopt the new GM cultivars because of its simplicity and flexibility of weed control that depends on only one herbicide to control a broad spectrum of weeds without crop injury. Globally, GM soybeans accounted for about $82 \%$ of the total soybean production area [114]. However, many countries are not deliberately growing genetically modified soybean, because of concern over its adverse impact on human health and environmental problems. The demand for non-GM soybean is relatively high in the European Union (EU), compared with other parts of the world. Of the number of soybean and soybean-derived products consumed by the EU, $95 \%$ are imported. The main use of soybean products in the EU is for animal feed [115]. Base on the Food and Agriculture Organization (FAO), bentazone was registered to use as herbicide for soybean seed and forage in France, Germany, Greece, Italy, Spain, the Netherlands, and the USA. In non-GMO (genetically modified organism) areas in EU and Asian countries, application of graminicides and bentazone can control simultaneously both grass and broadleaf weed in bentazone-resistant soybean field, which save time, labor, and application cost. Thus, it is important to develop bentazone-resistant soybeans for non-GM soybean production area.

Soybean resistance or tolerance to POST herbicide is essential. Soybean is a broadleaf plant, and weed control was mainly carried out by the PRE + POST herbicide application system before herbicide-resistant soybeans were produced mainly through genetic modification. However, there is a difference in the responses to bentazone among soybean genotypes; hence, it is necessary to select tolerant soybeans for breeding and for genetic studies. It is also necessary to understand inheritance of resistance to bentazone through population genetic studies such as a genome-wide association study. Several studies have reported on the genes that control bentazone tolerance in several crops; however, few genetic studies have been conducted in the past to clarify the molecular mechanisms of bentazone tolerance in soybean. This is most likely due to the advent of genetically modified herbicide tolerance as a significant selectivity method, as well as the production of strong target-site-specific mutant crops for specific herbicides.

Screening of soybean germplasm collections and mutation breeding to generate new genetic resources are to identify bentazone-resistant and bentazone-sensitive soybean accession. With genetic resources, advances in next-generation technology enable high-density genetic mapping and next-generation sequences (NGS) to identify QTL regions or candidate genes controlling the sensitivity or tolerance of soybean to bentazone. Through a QTL mapping study and NGS analyses, tightly flanked markers or gene-based markers are developed to use the marker-assisted selection for response to bentazone in a breeding program. Introgression of the QTLs or candidate genes responsible for xenobiotic detoxification of bentazone in soybean through conventional and molecular breeding approaches certainly warrants future investigations. Developing bentazone-tolerant soybean varieties can be fairly straightforward, as the source of tolerance is either an elite breeding line or a cultivar. Traditional and modern breeding methods will suffice to transfer resistance to elite breeding materials. When this trait is integrated into the high-yielding background, it will be possible to trade herbicide-tolerant varieties to growers that maintain their yield under herbicide stress conditions. Further increases in tolerance by an additive effect to bentazone may be possible by pyramiding genes controlling hydroxylation and glycosylation of bentazone from several tolerant genotypes in a natural population. In addition, using mutant lines as genetic resources will allow a future increase in bentazone tolerance, since tolerance in each mutant is regulated by a single gene, and the effects of these genes have been cumulative [116]. Since genotypic differences have already led to the development of metribuzin tolerance in lupin, soybean, and wheat $[117,118]$. stacking genes that control tolerance to different herbicides may be another option to combat resistant weeds. Recently, advances in CRISPR/Cas Genome editing via knockout, knock-in, replacement, and point mutation have enabled efficient modifications of a targeted gene controlling the response to bentazone in soybean, accelerating the development of new cultivars. In conclusion, it is necessary to conduct more research on finding new genes that control tolerance to better understand the tolerance mechanism and to assist in 
developing tolerant soybean varieties. Even though bentazone controls many broadleaf weeds, it is necessary to test the efficacy of bentazone in controlling various broadleaf weeds in various regions. Bentazone-tolerant soybean cultivars will greatly contribute to weed control in the field for conventional soybean production.

Author Contributions: L.A. drafted the manuscript. L.A. and H.J. analyzed the data. H.J., J.T.S. and J.-D.L. contributed critical comments to the draft and revised the manuscript. J.-D.L. conceptualized the manuscript. All authors have read and agreed to the published version of the manuscript.

Funding: This research was funded by a grant from the New breeding technologies development program (Project No. PJ01488301), Rural Development Administration, Republic of Korea.

Conflicts of Interest: The authors declare no conflict of interest.

\section{References}

1. Nigatu, L.; Sharma, J.J. Parthenium weed invasion and biodiversity loss in Ethiopia: A literature review. African Crop Sci. Conf. Proc. 2013, 11, 377-381.

2. Iderawumi, A.M. Characteristics Effects of Weed on Growth Performance and Yield of Maize (Zea mays). Biomed. J. Sci. Tech. Res. 2018, 7, 7-10. [CrossRef]

3. Oerke, E.C.; Dehne, H.W. Safeguarding production-Losses in major crops and the role of crop protection. Crop Prot. 2004, 23, 275-285. [CrossRef]

4. Cavigelli, M.A.; Teasdale, J.R.; Conklin, A.E. Long-term agronomic performance of organic and conventional field crops in the mid-Atlantic region. Agron. J. 2008, 100, 785-794. [CrossRef]

5. Basinger, N.T.; Jennings, K.M.; Monks, D.W.; Jordan, D.L.; Everman, W.J.; Hestir, E.L.; Bertucci, M.B.; Brownie, C. Large crabgrass (Digitaria sanguinalis) and Palmer amaranth (Amaranthus palmeri) intraspecific and interspecific interference in soybean. Weed Sci. 2019, 67, 649-656. [CrossRef]

6. United States Department of Agricutre Foreign Agricultural Service. Available online: https://www.fas.usda. gov/data/world-agricultural-production (accessed on 10 October 2020).

7. Kraehmer, H.; Laber, B.; Rosinger, C.; Schulz, A. Herbicides as Weed Control Agents: State of the Art: I. Weed Control Research and Safener Technology: The Path to Modern Agriculture. Plant Physiol. 2014, 166, 1119-1131. [CrossRef] [PubMed]

8. Abouziena, H.F.; Haggag, W.M. Weed Control in Clean Agriculture: A review. Planta Daninha 2016, 34, 377-392. [CrossRef]

9. Europe, S.P. Weed Control-Global Market Outlook (2017-2026); Stratistics Market Research: Secunderabad, India, June 2018.

10. Gianessi, L.; Sankula, S. The Value of Herbicides in U.S. Crop Production. Archeamatica 2003, 4, 46-51. [CrossRef]

11. Hull, H.M. Herbicide Handbook of the Weed Society of America; Humphrey Press: Geneva, NY, USA, 1976; 293p.

12. Shaner, D.L.; Beckie, H.J. The future for weed control and technology. Pest Manag. Sci. 2014, 70, 1329-1339. [CrossRef]

13. Milne, G.W.A. (Ed.) Pesticides: An International Guide to 1800 Pest Control Chemicals, 2nd ed.; Ashgate Publishing Ltd.: Hampshire, UK, 2004; ISBN 978-0-471-72334-9.

14. Wágner, G.; Nádasy, E. Effect of pre-emergence herbicides on growth parameters of green pea. Commun. Agric. Appl. Biol. Sci. 2006, 71, 809-813.

15. Sherwani, S.I.; Arif, I.A.; Khan, H.A. Modes of Action of Different Classes of Herbicides. Herbic. Physiol. Action Saf. 2015. [CrossRef]

16. Price, A.J.; Koger, C.H.; Wilcut, J.W.; Miller, D.; Van Santen, E. Efficacy of Residual And Non-Residual Herbicides Used in Cotton Production Systems When Applied with Glyphosate, Glufosinate, or MSMA. Weed Technol. 2008, 22, 459-466. [CrossRef]

17. Varshney, S.; Hayat, S.; Alyemeni, M.N.; Ahmad, A. Effects of herbicide applications in wheat fields: Is phytohormones application a remedy? Plant Signal Behav. 2012, 7, 570-575. [CrossRef] [PubMed]

18. Jugulam, M.; Shyam, C. Non-target-site resistance to herbicides: Recent developments. Plants 2019, 8, 417. [CrossRef] 
19. Vrbničanin, S.; Pavlović, D.; Božić, D. Weed Resistance to Herbicides. Herbic. Resist. Weeds Crop. 2017. [CrossRef]

20. Pan, G.; Zhang, X.; Liu, K.; Zhang, J.; Wu, X.; Zhu, J.; Tu, J. Map-based cloning of a novel rice cytochrome P450 gene CYP81A6 that confers resistance to two different classes of herbicides. Plant Mol. Biol. 2006, 61, 933-943. [CrossRef]

21. Singh, S.P.; Rawal, S.; Dua, V.K.; Roy, S.; Sharma, S.K. Evaluation of post emergence herbicide bentazon in potato crop. IJCS 2019, 7, 2816-2820.

22. Herrmann, C.M.; Goll, M.A.; Phillippo, C.J.; Zandstra, B.H. Postemergence weed control in onion with Bentazon, Flumioxazin, and Oxyfluorfen. Weed Technol. 2017, 31, 279-290. [CrossRef]

23. Zimdahl, R.L. Fundamentals of Weed Science, 5th ed.; Academic Press: Burlington, MA, USA, 2018; Chapter 16; pp. 463-499. ISBN 9780128111437.

24. Berger, S.; Ferrell, J.; Leon, R. Diagnosing Herbicide Injury in Cotton; University of Florida: Gainesville, FL, USA, 2015; pp. 1-9. Available online: https://edis.ifas.ufl.edu/ag367 (accessed on 29 August 2020).

25. Zhu, J.; Patzoldt, W.L.; Radwan, O.; Tranel, P.J.; Clough, S.J. Effects of Photosystem-II-Interfering Herbicides Atrazine and Bentazon on the Soybean Transcriptome. Plant Genome J. 2009, 2, 191. [CrossRef]

26. Han, Y.C.; Wang, C.Y. Physiological basis of bentazon tolerance in rice (Oryza sativa L.) lines. Weed Biol. Manag. 2002, 2, 186-193. [CrossRef]

27. Lichtenthaler, H.K.; Meier, D.; Retzlaff, G.; Hamm, R. Distribution and effects of bentazon in crop plants and weeds. Z. Naturforsch. Sect. C J. Biosci. 1982, 37, 889-897. [CrossRef]

28. Connelly, J.A.; Johnson, M.D.; Gronwald, J.W.; Wyse, D.L. Bentazon metabolism in tolerant and susceptible soybean (Glycine max) genotypes. Weed Sci. 1988, 417-423. [CrossRef]

29. Stoller, E.W.; Wax, L.M.; Matthiesen, R.L. Response of yellow nutsedge and soybeans to bentazon, glyphosate, and perfluidone. Weed Sci. 1975, 215-221. [CrossRef]

30. Bradshaw, L.D.; Barrett, M.; Poneleit, C.G. Physiological basis for differential bentazon susceptibility among corn (Zea mays) inbreds. Weed Sci. 1992, 522-527. [CrossRef]

31. Baltazar, A.M.; Monaco, T.J. Uptake, translocation, and metabolism of bentazon by two pepper species (Capsicum annuum and Capsicum chinese). Weed Sci. 1984, 258-263. [CrossRef]

32. Penner, D. Bentazone selectivity between soybean and Canada thistle. Weed Res. 1975, 15, 259-262. [CrossRef]

33. Galhano, V.; Peixoto, F.; Gomes-Laranjo, J.; Fernández-Valiente, E. Differential effects of bentazon and molinate on anabaena cylindrica, an autochthonous cyanobacterium of portuguese rice field agro-ecosystems. Water. Air. Soil Pollut. 2009, 197, 211-222. [CrossRef]

34. Allievi, L.; Gigliotti, C.; Salardi, C.; Valsecchi, G.; Brusa, T.; Ferrari, A. Influence of the herbicide bentazon on soil microbial community. Microbiol. Res. 1996, 151, 105-111. [CrossRef]

35. Lupwayi, N.Z.; Harker, K.N.; Clayton, G.W.; Turkington, T.K.; Rice, W.A.; O’Donovan, J.T. Soil microbial biomass and diversity after herbicide application. Can. J. Plant Sci. 2004, 84, 677-685. [CrossRef]

36. Meena, R.S.; Kumar, S.; Datta, R.; Lal, R.; Vijayakumar, V.; Brtnicky, M.; Pathan, S.I. Impact of agrochemicals on soil microbiota and management: A review. Land 2020, 9, 34. [CrossRef]

37. Levi, S.; Hybel, A.M.; Bjerg, P.L.; Albrechtsen, H.J. Stimulation of aerobic degradation of bentazone, mecoprop and dichlorprop by oxygen addition to aquifer sediment. Sci. Total Environ. 2014, 473-474, 667-675. [CrossRef] [PubMed]

38. Ke-bin, L.I.; Jing-tao, C.; Xiao-fang, W.; Ying, Z.; Wei-ping, L.I.U. Degradation of Herbicides Atrazine and Bentazone Applied Alone and in Combination in Soils. Pedosphere 2008, 18, 265-272.

39. Rose, M.T.; Cavagnaro, T.R.; Scanlan, C.A.; Rose, T.J.; Vancov, T.; Kimber, S.; Van Zwieten, L. Impact of herbicides on soil biology and function. In Advances in Agronomy; Academic Press: Cambridge, MA, USA, 2016; Volume 136, pp. 133-220.

40. Federal Register. Available online: https://www.federalregister.gov/documents/2019/05/01/2019-08785/ bentazon-pesticide-tolerances\#print (accessed on 10 October 2020).

41. Food and Agriculture Organization. Available online: http://www.fao.org/3/a-i3518e.pdf (accessed on 10 October 2020).

42. Acquavella, J.; Doe, J.; Tomenson, J.; Chester, G.; Cowell, J.; Bloemen, L. Epidemiologic studies of occupational pesticide exposure and cancer: Regulatory risk assessments and biologic plausibility. Ann. Epidemiol. 2003, 13, 1-7. [CrossRef] 
43. Varanasi, A.; Prasad, P.V.V.; Jugulam, M. Impact of Climate Change Factors on Weeds and Herbicide Efficacy. In Advances in Agronomy; Academic Press: Burlington, MA, USA, 2016; Volume 135, pp. 107-146. ISBN 9780128046937.

44. Kudsk, P.; Kristensen, J. Effect of environmental factors on herbicide performance. In Proceedings of the First International Weed Control Congress, Melbourne, Australia, 17-21 February 1992; Weed Science Society of Victoria: Victoria, Australia, 1992; pp. 173-186.

45. Matzenbacher, F.O.; Vidal, R.A.; Merotto, A.; Trezzi, M.M. Environmental and physiological factors that affect the efficacy of herbicides that inhibit the enzyme protoporphyrinogen oxidase: A literature review. Planta Daninha 2014, 32, 457-463. [CrossRef]

46. Anderson, D.M.; Swanton, C.J.; Hall, J.C.; Mersey, B.G. The influence of temperature and relative humidity on the efficacy of glufosinate-ammonium. Weed Res. 1993, 33, 139-147. [CrossRef]

47. Mine, A.; Matsunaka, S. Mode of action of bentazon: Effect on photosynthesis. Pestic. Biochem. Physiol. 1975, 5, 444-450. [CrossRef]

48. Kudsk, P. Optimising herbicide performance. In Weed Management Handbook, 9th ed.; Naylor, R.E.L., Ed.; Blackwell Science: Oxford, UK, 2002; pp. 323-344.

49. Vencill, W.; Grey, T.; Culpepper, S. Resistance of Weeds to Herbicides. Herbic. Environ. 2011. [CrossRef]

50. Ohkawa, H.; Tsujii, H.; Ohkawa, Y. The use of cytochrome P450 genes to introduce herbicide tolerance in crops: A review. Pestic. Sci. 1999, 55, 867-874. [CrossRef]

51. Peterson, D.; Thompson, C.; Shoup, D.; Jugulam, M. Herbicide Mode of Action; Kansas State University: Manhattan, KS, USA, May 2015; Available online: https://bookstore.ksre.ksu.edu/pubs/c715.pdf (accessed on 29 August 2020).

52. Hayes, R.M.; Wax, L.M. Differential Intraspecific Responses of Soybean Cultivars to Bentazon. Weed Sci. 1975, 23, 516-521. [CrossRef]

53. Huber, R.; Otto, S. Environmental behavior of bentazon herbicide. Rev. Environ. Contam. Toxicol. 1994, 137, 111-134. [CrossRef]

54. Anastassiadou, M.; Brancato, A.; Cabrera, L.C.; Ferreira, L.; Greco, L.; Jarrah, S.; Kazocina, A.; Leuschner, R.; Magrans, J.O.; Miron, I.; et al. Modification of the existing maximum residue levels for bentazone in soyabeans and poppy seeds. EFSA J. 2019, 17, e05798. [CrossRef] [PubMed]

55. Burton, J.D.; Maness, E.P. Constitutive and inducible bentazon hydroxylation in shattercane (Sorghum bicolor) and Johnsongrass (S. halapense). Pestic. Biochem. Physiol. 1992, 44, 40-49. [CrossRef]

56. McFadden, J.J.; Gronwald, J.W.; Eberlein, C.V. In vitro hydroxylation of bentazon by microsomes from naphthalic anhydride-treated corn shoots. Biochem Biophys Res Commun. 1990, 168, 206-213. [CrossRef]

57. Yu, Q.; Powles, S. Metabolism-based herbicide resistance and cross-resistance in crop weeds: A threat to herbicide sustainability and global crop production. Plant Physiol. 2014, 166, 1106-1118. [CrossRef]

58. Siminszky, B. Plant cytochrome P450-mediated herbicide metabolism. Phytochem. Rev. 2006, 5, 445-458. [CrossRef]

59. De Montellano, P.R.O. 1-Aminobenzotriazole: A Mechanism-Based Cytochrome P450 Inhibitor and Probe of Cytochrome P450 Biology. Med. Chem. 2018, 8, 38-65. [CrossRef]

60. Nohatto, M.A.; Agostinetto, D.; Langaro, A.C.; de Oliveira, C.; Ruchel, Q. Antioxidant activity of rice plants sprayed with herbicides. Pesqui. Agropecuária Trop. 2016, 46, 28-34. [CrossRef]

61. Fleming, A.A.; Banks, P.A.; Legg, J.G. Differential response of maize inbreds to bentazon and other herbicides. Can. J. Plant Sci. 1988, 68, 501-507. [CrossRef]

62. Eberlein, C.V.; Guttieri, M.J.; Fletcher, F.E. Postemergence directed application of bentazon + metribuzin for broadleaf weed control in Russet Burbank potatoes. Am. Potato J. 1996, 73, 135-141. [CrossRef]

63. Nosratti, I.; Mahdavi-Rad, S.; Heidari, H.; Saeidi, M. Differential tolerance of pumpkin species to bentazon, metribuzin, trifluralin and oxyfluorfen. Planta Daninha 2017, 35. [CrossRef]

64. Harrison, H.F.; Fery, R.L. Differential Bentazon Response in Cowpea (Vigna unguiculata). Weed Technol. 1993, 7, 756-758. [CrossRef]

65. Soltani, N.; Nurse, R.E.; Robinson, D.E.; Sikkema, P.H. Response of Pinto and Small Red Mexican Bean to Postemergence Herbicides. Weed Technol. 2008, 22, 195-199. [CrossRef]

66. Fery, R.L.; Harrison, H.F. Characterization of the bentazon herbicide tolerance factor in "Bohemian Chili" pepper. HortScience 1999, 34, 125-126. [CrossRef] 
67. Jordan, D.L.; Spears, J.F.; Wilcut, J.W. Tolerance of Peanut (Arachis hypogaea L.) to Herbicides Applied Postemergence. Peanut Sci. 2003, 30, 8-13. [CrossRef]

68. McCurdy, J.D.; McElroy, J.S.; Flessner, M.L. Differential Response of Four Trifolium Species to Common Broadleaf Herbicides: Implications for Mixed Grass-Legume Swards. Weed Technol. 2013, 27, 123-128. [CrossRef]

69. Burgess, P.; Haverstock, J.; Wood, S. Guide to Weed Management in Highbush Blueberry. 2018. Available online: https://www.perennia.ca/wp-ontent/uploads/2018/03/Highbush-blueberry-weed-control-Guide_ 2018a.pdf (accessed on 26 August 2020).

70. Leah, J.M.; Worrall, T.L.; Cobb, A.H. Isolation and characterisation of two glucosyltransferases from Glycine max associated with bentazone metabolism. Pestic. Sci. 1992, 34, 81-87. [CrossRef]

71. Zhang, L.; Lu, Q.; Chen, H.; Pan, G.; Xiao, S.; Dai, Y.; Li, Q.; Zhang, J.; Wu, X.; Wu, J.; et al. Identification of a cytochrome $\mathrm{P} 450$ hydroxylase, CYP81A6, as the candidate for the bentazon and sulfonylurea herbicide resistance gene, Bel, in rice. Mol. Breed. 2007, 19, 59-68. [CrossRef]

72. Fang, Y.; Lu, H.; Chen, S.; Zhu, K.; Song, H.; Qian, H. Leaf proteome analysis provides insights into the molecular mechanisms of bentazon detoxification in rice. Pestic. Biochem. Physiol. 2015, 125, 45-52. [CrossRef]

73. Bernard, R.L.; Wax, L.M. Inheritance of a sensitive reaction to bentazon herbicide. Soybean Genet. Newsl. 1975, 2, 46-47.

74. Kato, S.; Yokota, Y.; Suzuki, R.; Fujisawa, Y.; Sayama, T.; Kaga, A.; Anai, T. Identification of a cytochrome P450 hydroxylase, CYP81E22, as a causative gene for the high sensitivity of soybean to herbicide bentazon. Theor. Appl. Genet. 2020. [CrossRef]

75. Bradshaw, L.D.; Barrett, M.; Poneleit, C.G. Inheritance of bentazon susceptibility in a corn (Zea mays) line. Weed Sci. 1994, 641-647. [CrossRef]

76. Nordby, J.N.; Williams, M.M.; Pataky, J.K.; Riechers, D.E.; Lutz, J.D. A common genetic basis in sweet corn inbred Cr1 for cross sensitivity to multiple cytochrome P450-metabolized herbicides. Weed Sci. 2008, 56, 376-382. [CrossRef]

77. Wolff, D.W.; Collins, W.W.; Monaco, T.J. Inheritance of Tolerance to the Herbicide Bentazon in Peppers (Capsicum annuum L.). J. Am. Soc. Hortic. Sci. 1992, 117, 985-990. [CrossRef]

78. Shelton, A.; Shaw, D. Green Genes: Sustainability Advantages of Herbicide Tolerant and Insect Resistant Crops. Available online: https://geneticliteracyproject.org/2014/12/02/green-genes-sustainability-advantagesof-herbicide-tolerant-and-insect-resistant-crops (accessed on 10 October 2020).

79. Ke, L.; Liu, R.; Chu, B.; Yu, X.; Sun, J.; Jones, B.; Pan, G.; Cheng, X.; Wang, H.; Zhu, S.; et al. Cell Suspension Culture-Mediated Incorporation of the Rice Bel Gene into Transgenic Cotton. PLoS ONE 2012, 7. [CrossRef]

80. Khan, M.D.; Mei, L.; Raza, I.; Deeba, F.; Hassan, S.; Zhu, S.J. Agrobacterium-mediated Genetic Transformation of Bentazon Resistant Gene (Cyp81A6) in Cotton. J. Bio Mol. Sci. 2013, 1, 17-26.

81. Liu, C.; Liu, S.; Wang, F.; Wang, Y.; Liu, K. Expression of a rice CYP81A6 gene confers tolerance to bentazon and sulfonylurea herbicides in both Arabidopsis and tobacco. Plant Cell. Tissue Organ Cult. 2012, 109, 419-428. [CrossRef]

82. Yamada, T.; Ohashi, Y.; Ohshima, M.; Inui, H.; Shiota, N.; Ohkawa, H.; Ohkawa, Y. Inducible cross-tolerance to herbicides in transgenic potato plants with the rat CYP1A1 gene. Theor. Appl. Genet. 2002, 104, 308-314. [CrossRef]

83. Goldsmith, P.D. Economics of Soybean Production, Marketing, and Utilization. Soybeans Chem. Prod. Process. Util. 2008, 117-150. [CrossRef]

84. Buhler, D.D.; Hartzler, R.G.; Forcella, F. Implications of weed seedbank dynamics to weed management. Weed Sci. 1997, 45, 329-336. [CrossRef]

85. Vivian, R.; Reis, A.; Kálnay, P.A.; Vargas, L.; Ferreira, A.C.C.; Mariani, F. Weed Management in Soybean -Issues and Practices. In Soybean-Pest Resistance; El-Shemy, H.A., Ed.; IntechOpen Limited: London, UK; Rijeka, Croatia, 2013; p. 290.

86. El-Nahhal, Y.; Hamdona, N. Phytotoxicity of Alachlor, Bromacil and Diuron as single or mixed herbicides applied to wheat, melon, and molokhia. Springerplus 2015. [CrossRef]

87. Soltani, N.; Nurse, R.E.; Sikkema, P.H. Weed Management in Kidney Bean with Tank Mixes of S-Metolachlor, Imazethapyr and Linuron. Agric. Sci. 2014, 5, 611-617. [CrossRef] 
88. Bond, J.A.; Lawrence, B.H.; Bararpour, T.M.; Dodds, D.M.; Golden, B.R.; Irby, J.T.; Larson, E.J.; Reynolds, D.B. (Eds.) Weed Management Suggestions for Mississippi Row Crops. 2019. Available online: https://extension. msstate.edu/sites/default/files/publications/publications/p3171.pdf (accessed on 29 August 2020).

89. Hager, A.G.; Wax, L.M.; Bollero, G.A.; Stoller, E.W. Influence of diphenylether herbicide application rate and timing on common waterhemp (Amaranthus rudis) control in soybean (glycine max). Weed Technol. 2003, 17, 14-20. [CrossRef]

90. Green, J.M.; Owen, M.D.K. Herbicide-resistant crops: Utilities and limitations for herbicide-resistant weed management. J. Agric. Food Chem. 2011, 59, 5819-5829. [CrossRef] [PubMed]

91. Soybean Herbicide Guide, Syngenta. 2019. Available online: https://www.syngenta-us.com/prodrender/ imagehandler.ashx?ImID=DE713DB6-BBB5-4F0A-BA9C-54448F9A10DF\&fTy=0\&et=8 (accessed on 26 August 2020).

92. Dayan, F.E.; Duke, S.O. Protoporphyrinogen Oxidase-Inhibiting Herbicides. In Hayes' Handbook of Pesticide Toxicology, 3rd ed.; Hayes, W.J., Ed.; Elsevier Inc.: San Diego, CA, USA, 2010; Volume 2, pp. 1733-1751.

93. Almarie, A.A. The critical period for weed competition in soybean (Glycine max) under Iraqi irrigated areas. ARPN J. Agril. Biol. Sci. 2017, 4, 128-132.

94. Scursoni, J.A.; Satorre, E.H. Glyphosate management strategies, weed diversity and soybean yield in Argentina. Crop Prot. 2010, 29, 957-962. [CrossRef]

95. Carpenter, J.E. Comparing Roundup Ready and Conventional Soybean Yields 1999; National Center for Food and Agricultural Policy: Washington, DC, USA, 2001; p. 20036.

96. Williams, M.M.; Nelson, R.L. Vegetable Soybean Tolerance to Bentazon, Fomesafen, Imazamox, Linuron, and Sulfentrazone. Weed Technol. 2014, 28, 601-607. [CrossRef]

97. Meseldžija, M.; Rajković, M.; Dudić, M.; Vranešević, M.; Bezdan, A.; Jurišić, A.; Ljevnaić-Mašić, B. Economic Feasibility of Chemical Weed Control in Soybean Production in Serbia. Agronomy 2020, 10, 291. [CrossRef]

98. Davidson, B.; Cook, T.; Chauhan, B.S. Alternative Options to Glyphosate for Control of Large Echinochloa colona and Chloris virgata Plants in Cropping Fallows. Plants 2019, 8, 245. [CrossRef]

99. Tachibana, M.; Nakayama, S.; Watanabe, H. Response of soybean cultivars to bentazon in the Tohoku region, Japan. J. Weed Sci. Technol. 2006, 51, 19-27. [CrossRef]

100. Kapusta, G.; Jackson, L.A.; Mason, D.S. Yield Response of Weed-Free Soybeans (Glycine max) to Injury from Postemergence Broadleaf Herbicides. Weed Sci. 1986, 34, 304-307. [CrossRef]

101. Barrentine, W.L.; Street, J.E.; Eddie, J. Soybean Response to Quinclorac and Triclopyr; Department of Information Services, Division of Agriculture, Forestry, and Veterinary Medicine, Mississippi State University: Starkville, MS, USA, 1993; Volume 995.

102. Belfry, K.D.; Soltani, N.; Brown, L.R.; Sikkema, P.H. Tolerance of identity preserved soybean cultivars to preemergence herbicides. Can.J. Plant Sci. 2015, 95, 719-726. [CrossRef]

103. Franzen, D.W.; O'Barr, J.H.; Zollinger, R.K. Interaction of a foliar application of iron HEDTA and three postemergence broadleaf herbicides with soybeans stressed from chlorosis. J. Plant Nutr. 2003, 26, 2365-2374. [CrossRef]

104. Ivany, J.A.; Reddin, J. Effect of post-emergence herbicide injury and planting date on yield of narrow-row soybean (Glycine max). Can. J. Plant Sci. 2002, 82, 249-252. [CrossRef]

105. Lich, J.M.; Renner, K.A.; Penner, D. Interaction of glyphosate with postemergence soybean (Glycine max) herbicides. Weed Sci. 1997, 12-21. [CrossRef]

106. Palmer, E.W.; Shaw, D.R.; Holloway, J.C. Broadleaf weed control in soybean (Glycine max) with CGA-277476 and four postemergence herbicides. Weed Technol. 2000, 14, 617-623. [CrossRef]

107. Ritter, R.L.; Harris, T.C.; Kaufman, L.M. Chlorsulfuron and metsulfuron residues on double-cropped soybeans (Glycine max). Weed Technol. 1988, 49-52. [CrossRef]

108. Wichert, R.A.; Talbert, R.E. Soybean [Glycine max (L.)] response to lactofen. Weed Sci. 1993, 23-27. [CrossRef]

109. Young, B.G.; Young, J.M.; Matthews, J.L. Soybean (Glycine max) Response to Foliar Applications of Mesotrione1. Weed Technol. 2003, 17, 651-654. [CrossRef]

110. Wixson, M.B.; Shaw, D.R. Differential Response of Soybean (Glycine max) Cultivars to AC 263,222. Weed Technol. 1991, 5, 430-433. [CrossRef]

111. Wax, L.M.; Bernard, R.L.; Hayes, R.M. Response of soybean cultivars to bentazon, bromoxynil, chloroxuron, and 2,4-DB. Weed Sci. 1974, 22, 35-41. [CrossRef] 
112. Abugho, S.B. Weed Control and Management for Vegetable Soybeans in Arkansas. Ph.D. Thesis, University of Arkansas, Fayetteville, AR, USA, December 2018.

113. Lee, C.; Choi, M.-S.; Kim, H.T.; Yun, H.T.; Lee, B.; Chung, Y.S.; Kim, R.W.; Choi, H.K. Soybean [Glycine max (L.) Merrill]: Importance as a Crop and Pedigree Reconstruction of Korean Varieties. Plant Breed. Biotechnol. 2015, 3, 179-196. [CrossRef]

114. Wong, A.Y.T.; Chan, A.W.K. Genetically modified foods in China and the United States: A primer of regulation and intellectual property protection. Food Sci. Human Wellness 2016, 5, 124-140. [CrossRef]

115. Tillie, P.; Rodríguez-Cerezo, E. Markets for non-Genetically Modified, Identity-Preserved soybean in the EU. JRC Sci. Policy Rep. 2015, 1-72. [CrossRef]

116. Si, P.; Yan, G.; Kamsan, M.A.; Adhikari, K.N. Genotypic variation of metribuzin and carfentrazone-ethyl tolerance among yellow lupin (Lupinus luteus L.) germplasm. N. Zeal. J. Crop Hortic. Sci. 2012, 40, 43-54. [CrossRef]

117. Si, P.; Sweetingham, M.W.; Buirchell, B.J.; Bowran, D.G.; Piper, T. Genotypic variation in metribuzin tolerance in narrow-leafed lupin (Lupinus angustifolius L.). Aust. J. Exp. Agric. 2006, 46, 85-91. [CrossRef]

118. Kleemann, S.G.L.; Gill, G.S. Differential tolerance in wheat (Triticum aestivum L.) genotypes to metribuzin. Aust. J. Agric. Res. 2007, 58, 452-456. [CrossRef]

Publisher's Note: MDPI stays neutral with regard to jurisdictional claims in published maps and institutional affiliations.

(C) 2020 by the authors. Licensee MDPI, Basel, Switzerland. This article is an open access article distributed under the terms and conditions of the Creative Commons Attribution (CC BY) license (http://creativecommons.org/licenses/by/4.0/). 